\title{
Inhibition of Curcumin-Treated Herpes Simplex Virus 1 and 2 in Vero Cells
}

\author{
Daniel J. Flores, Lee H. Lee, Sandra D. Adams* \\ Department of Biology, Montclair State University, Montclair, USA \\ Email: *adamssa@mail.montclair.edu
}

Received 4 February 2016; accepted 10 April 2016; published 13 April 2016

Copyright (C) 2016 by authors and Scientific Research Publishing Inc.

This work is licensed under the Creative Commons Attribution International License (CC BY).

http://creativecommons.org/licenses/by/4.0/

(c) (i) Open Access

\begin{abstract}
The purpose of this study was to investigate the effect of curcumin-treated Herpes simplex virus-1 (HSV-1) and Herpes simplex virus-2 (HSV-2) virions in cultured Vero cells. Previous studies have indicated that curcumin, a polyphenol extracted from the plant Curcuma longa, has demonstrated antiviral properties against a variety of viruses. After establishing the maximum non-cytotoxic concentrations of curcumin on Vero cells, HSV-1 and HSV-2 virions were treated with varying concentrations of curcumin. The effect on infectivity was determined by antiviral assays, using WST-1, plaque assays, adsorption and penetration assays. Treating HSV-1 and HSV-2 viruses with curcumin, at a concentration of $30 \mu \mathrm{M}$, reduces the production of infectious HSV-1 and HSV-2 virions in cultured Vero cells by interfering with the adsorption process. These results support the potential of curcumin to be used as a therapeutic agent to reduce the transmission of $\mathrm{HSV}-1$ and HSV-2.
\end{abstract}

\section{Keywords}

HSV-1, HSV-2, Curcuma Longa, Curcumin, Vero Cells, Adsorption, Antiviral

\section{Introduction}

Herpes simplex virus 1 (HSV-1) and Herpes simplex virus 2 (HSV-2) (family Herpesviridae, subfamily Alphaherpesvirinae) are transferred among humans via an oral or sexual route [1] [2]. To initiate lytic infection, HSV virions must attach to cellular receptors, and then fuse their envelopes with host cell plasma membranes [3]-[5]. This process of adsorption is followed by penetration and transport of the encapsidated DNA genome to the nuclear pore, where the viral DNA is released [6]. Following infection of epithelial cells, HSV is able to migrate

${ }^{*}$ Corresponding author. 
to the spinal ganglions where lifelong latent infection is established. Periodic outbreaks occur due to reactivation, resulting in viral shedding from lesions [7].

HSV-1, a common infection in children, is most commonly associated with oral lesions while HSV-2 is associated with genital lesions [1] [6] [8]. However, HSV-1 is emerging as a cause of genital herpes in some developed countries, especially among young adults [8]. Most cases of genital herpes are asymptomatic [9] but transmission of HSV can occur during asymptomatic viral shedding [10].

Worldwide the incidence of HSV-1 or HSV-2 is estimated between $65 \%$ and $90 \%$ of the total population. HSV-1 is the most prevalent in the United States and in Europe whereas developing countries have a much higher incidence of HSV-2 infections [11]-[16]. Sero-prevalence of HSV-2 increases with increased sexual activity [9]. Current treatments that work to reduce transmission of HSV are not cost effective and are hard to obtain in under-developed countries where HSV is the most prevalent [17].

Recently, plant derived products have gained popularity as promising antiviral agents [18]-[24]. One of the promising interests is curcumin (diferuloylmethane), a polyphenol extracted from the plant Curcuma longa, a member of the ginger family Zingiberaceae. Curcumin (PubChem CID: 969516), a phenolic compound from the spice turmeric, is widely abundant and cost effective. This compound is demonstrated to contain antioxidant, anti-inflammatory, and antitumor properties [25]-[28]. Curcumin has also been demonstrated to have antiviral properties against hepatits B, hepatits C, influenza, enterovirus 71, and dengue virus [29]-[35]. Additionally, treatment of cells with curcumin has been demonstrated to inhibit immediate-early gene expression of HSV-1 [36]. Treatment with curcumin also resulted in protection against intravaginal challenge by HSV-2 in mice [36]. These studies demonstrate that curcumin acts to inhibit virus infection by multiple modes of action and indicate that curcumin warrants further investigation as an antiviral agent against herpes simplex viruses. The purpose of this study is to investigate the effect of curcumin-treated HSV-1 and HSV-2 virions in cultured Vero cells.

\section{Materials and Methods}

\subsection{Cell Culture}

Vero cells [ATCC (Manassas, VA)] were cultured until confluent in vented flasks in Dulbecco's Modified Eagle Medium (DMEM) with 5\% fetal bovine serum (FBS) and $1 \mu \mathrm{g} / \mathrm{mL}$ gentamicin at $37^{\circ} \mathrm{C}$ and $5 \% \mathrm{CO}_{2}$.

\subsection{HSV-1 and HSV-2 Virus Maintenance}

A recombinant strain of HSV-1, GHSV-UL46, which contains the sequence for green fluorescent protein (GFP) fused to the tegument protein pUL46 (ATCC, Manassas, VA, USA) and HSV-2VP26-GFP which expresses a fusion protein of VP26 and GFP (generously donated by Dr. Andrea Bertke, Virginia Tech University) were used in all experiments. Passage of virus was performed in T-25 flasks and cells were allowed to reach complete cytopathic effect (CPE). The viral media were then collected, centrifuged, and the supernatants containing viruses were kept in cryogenic vials at $-80^{\circ} \mathrm{C}$.

\subsection{Preparation of Curcumin}

Curcumin (Sigma-Aldrich, St; Louis, MO) was dissolved in dimethylsulfoxide (DMSO) to produce an initial stock concentration of $15 \mathrm{mM}$, stored at $-20^{\circ} \mathrm{C}$. Further dilutions $(10-100 \mu \mathrm{M})$ of the stock solution were freshly prepared in $5 \%$ FBS-DMEM as needed to yield $<0.2 \%$ DMSO in solution.

\subsection{Curcumin Cytotoxicity}

\subsubsection{Cell Viability with Trypan Blue Assay}

Vero cells were plated in 6-well plates, and after 24 hours, different concentrations of curcumin were added to each well. After one hour, the curcumin was aspirated and the cells were washed with PBS, and cells, including positive and negative control groups, were incubated with 5\% FBS-DMEM for 48 hours. Cells were then stained with trypan blue and quantified using a hemocytometer. The $\%$ of viability was calculated as follows:

$\%$ Viability $=$ (unstained viable cells treated/unstained viable cell control $) \times 100$.

Triplicate experiments were carried out and the percent viability was represented by the mean and standard deviation (SD). 


\subsubsection{Cell Proliferation Assay}

Vero cells were cultured in 96-well plates for 24 hours then treated with various concentrations of curcumin for 1hour.Cell proliferation reagent WST-1 [2-(4-Iodophenyl)-3-(4-nitrophenyl)-5-(2, 4-disulfophenyl)-2H-tetrazolium, monosodium salt] (Roche Diagnostics, Indianapolis, IN, USA) $(10 \mu \mathrm{L})$ was added to each well that contained a sample 24 hours post-treatment; controls included $100 \mu \mathrm{L}$ of $5 \%$ FBS-DMEM both with and without the $10 \mu \mathrm{L}$ of WST-1 reagent. The plate was gently rocked to mix the WST-1 reagent with each sample, and then placed in an incubator at $37^{\circ} \mathrm{C}$ and $5 \% \mathrm{CO}_{2}$ for 2 hours. The absorbance level for each well was measured at 450 $\mathrm{nm}$ in a microplate reader. The \% of growth was calculated as follows.

Percent growth $=\left(\mathrm{OD}_{450}\right.$ of treated $/ \mathrm{OD}_{450}$ of control $) \times 100$.

Triplicate experiments were carried out and the percent growth was represented by the mean and standard deviation (SD).

\subsection{WST-1 Antiviral Assay}

Vero cells were cultured in 96 well plates for 24 hours. $100 \mu \mathrm{L}$ of $2 \mathrm{X}$ curcumin solutions $(10 \mu \mathrm{M}, 20 \mu \mathrm{M}, 30$ $\mu \mathrm{M}, 40 \mu \mathrm{M}$ and $50 \mu \mathrm{M}$ ) were mixed with $100 \mu \mathrm{L}$ of HSV-1 and HSV-2 in microfuge tubes and incubated at room temperature for 1 hour. Then, $100 \mu \mathrm{L}$ of each mixture was added to a separate well on a 96-well plate containing Vero cells, from which the media had been aspirated. The plates were incubated at $37^{\circ} \mathrm{C}$ and $5 \% \mathrm{CO}_{2}$ for 1 hour and rocked every 15 minutes. After 1 hour, any unabsorbed virus was aspirated and $100 \mu 1$ of 5\% FBS-media was added to each well, and incubated at $37^{\circ} \mathrm{C}$ and $5 \% \mathrm{CO}_{2}$ for 24 hours. $10 \mu \mathrm{L}$ of WST- 1 reagent (Roche Diagnostics, Indianapolis, IN, USA) was added 24 hours post treatment to each well that contained a sample; controls included $100 \mu \mathrm{L}$ of $5 \%$ FBS-DMEM both with and without the $10 \mu \mathrm{L}$ of WST-1 reagent. The plate was gently rocked to mix the WST-1 reagent with each sample, and then placed in an incubator at $37^{\circ} \mathrm{C}$ and $5 \% \mathrm{CO}_{2}$ for 2 hours. The absorbance level for each well was measured at $450 \mathrm{~nm}$ in a microplate reader. The percent of inhibition was calculated as follows.

Percent inhibition $=($ treated $\mathrm{HSV} \mathrm{OD} 450$-untreated HSV OD 450$) /\left(\right.$ cells $\mathrm{OD}_{450}$-untreated $\left.\mathrm{HSV} \mathrm{OD} 450\right) \times 100$ [38].

Triplicate experiments were carried out and the percent growth was represented by the mean and standard deviation (SD).

\subsection{Viral Inhibition Assay}

$100 \mu \mathrm{L}$ of $2 \times$ curcumin solutions were mixed with $100 \mu \mathrm{L}$ of HSV-1 and HSV-2 in microcentrifuge tubes at final concentrations of $10 \mu \mathrm{M}, 20 \mu \mathrm{M}, 30 \mu \mathrm{M}, 40 \mu \mathrm{M}$ and $50 \mu \mathrm{M}$ and incubated at room temperature for 1 hour. A sample without treatment was used as positive and a sample containing $100 \mu \mathrm{L}$ of $5 \%$ FBS-DMEM was used as negative control. Then, $200 \mu \mathrm{L}$ of each mixture was added to a separate well on a 6-well plate containing Vero cells, from which the media had been aspirated. The plates were incubated at $37^{\circ} \mathrm{C}$ and $5 \% \mathrm{CO}_{2}$ for 1 hour and rocked every 15 minutes. After 1 hour, any unabsorbed virus was aspirated and $2.5 \mathrm{~mL}$ of $5 \%$ FBS-media was added to each well of Vero cells, and incubated at $37^{\circ} \mathrm{C}$ and $5 \% \mathrm{CO}_{2}$ for 48 hours. Virus titers were determined by plaque assays.

\subsection{Viral Titer Determination using Plaque Assay}

Ten-fold serial dilutions, $10^{-1}$ to $10^{-6}$, of HSV-1, HSV-2, and virus-treated extracts of HSV-1 and HSV-2 were prepared prior to infection. Confluent Vero cell monolayers were then infected with $100 \mu \mathrm{L}$ of viral dilutions ranging from $10^{-3}-10^{-6}$ in full log increments, and allowed to adsorb for 1 hour at $37^{\circ} \mathrm{C}$ and $5 \% \mathrm{CO}_{2}$. Unabsorbed viruses were aspirated, and plates were then overlaid with a nutrient medium-containing $4 \%$ Oxoid agar (Thermo Scientific) and incubated for 72 hours. The plaques were visualized by staining cells with crystal violet and removing agar. The number of plaque-forming units was determined within 50 hours and the percent of inhibition was calculated as follows.

Percent of inhibition $=(1-\mathrm{PFU}$ of treated/PFU of untreated $) \times 100$.

\subsection{Fluorescent Microscopy}

To visualize the effect that the $30 \mu \mathrm{M}$ curcumin had on viral propagation, Vero cells were placed on coverslips 
within 12 well plates and allowed to reach confluency (48 hours). The curcumin treated virus assay was conducted, as previously described. Cells were stained with $300 \mu \mathrm{L}$ of $300 \mathrm{nM}$ DAPI (4, 6-diamidino-2-phenylindole) stain for $5 \mathrm{~min}$. at $37^{\circ} \mathrm{C}$ in the dark. Cells were then fixed with $2 \%-4 \%$ paraformaldehyde solution for 10 - 20 min. then rinsed briefly with PBS. The cover slip containing cells were mounted to a slide with a solution of $90 \%$ glycerol and 10\% PBS and permanently sealed around the perimeter using clear nail polish. Cells were then visualized under a Zeiss Axiovision fluorescence microscope with a digital camera with the magnification of $400 \times$ or $1000 \times$.

\subsection{Viral Adsorption Assay}

Equal volumes $(100 \mu \mathrm{L})$ of $30 \mu \mathrm{M}$ curcumin and a virus suspension, containing virus to yield $20-30$ plaques per well, were placed in microcentrifuge tubes, and the mixtures were incubated at $37^{\circ} \mathrm{C}$ for 1 hour. FBSDMEM without virus was used as the negative control and untreated virus suspensions served as the positive control. The samples were then placed on monolayers of Vero cells in 6-well plates and the virus was allowed to adsorb in the presence of the curcumin. Unabsorbed solutions were aspirated, and nutrient medium-containing agar was then added to each of the wells, and the plates were incubated at $37^{\circ} \mathrm{C}$ and $5 \% \mathrm{CO}_{2}$ for 3 days. Adsorption efficiency was assessed by counting plaques, as described above.

\subsection{Viral Penetration Assay}

Virus suspensions were prepared on ice to produce 20 - 30 plaques per well on monolayers of Vero cells in 6 -well plates. Virus suspensions were placed on cells, and plates were incubated at $4^{\circ} \mathrm{C}$ for 2 hours to allow attachment. Curcumin $(30 \mu \mathrm{M})$ was then added to the wells at room temperature and plates were incubated at $37^{\circ} \mathrm{C}$ for 10 minutes to allow penetration. Untreated cells were used as controls. Unattached virions were then washed off with PBS, and unabsorbed solutions were aspirated. Nutrient medium-containing agar was then added to each of the wells, including positive and negative controls, and the plates were incubated at $37^{\circ} \mathrm{C}$ and $5 \% \mathrm{CO}_{2}$ for 3 days. Plaques were counted as described above.

\section{Results}

\section{1. Cell Viability Study with Trypan Blue Assay}

The cells were treated with different concentrations of curcumin $(0,10,20,30,40,50,60,70,80,90$, and 100 $\mu \mathrm{M}$ ) for 1 hour and then incubated for 48 hours at $37^{\circ} \mathrm{C}$. The cell viability was determined by using trypan blue and hemacytometer direct cell count to detect the effect of curcumin on Vero cells. The results illustrated the mean of three replicas and SD in percent viability is shown in Figure 1. It is indicated that Vero cells respond to curcumin in a dose-dependent manner: for concentrations of 10 and $20 \mu \mathrm{M}$, the percent viability is $96 \%$ and

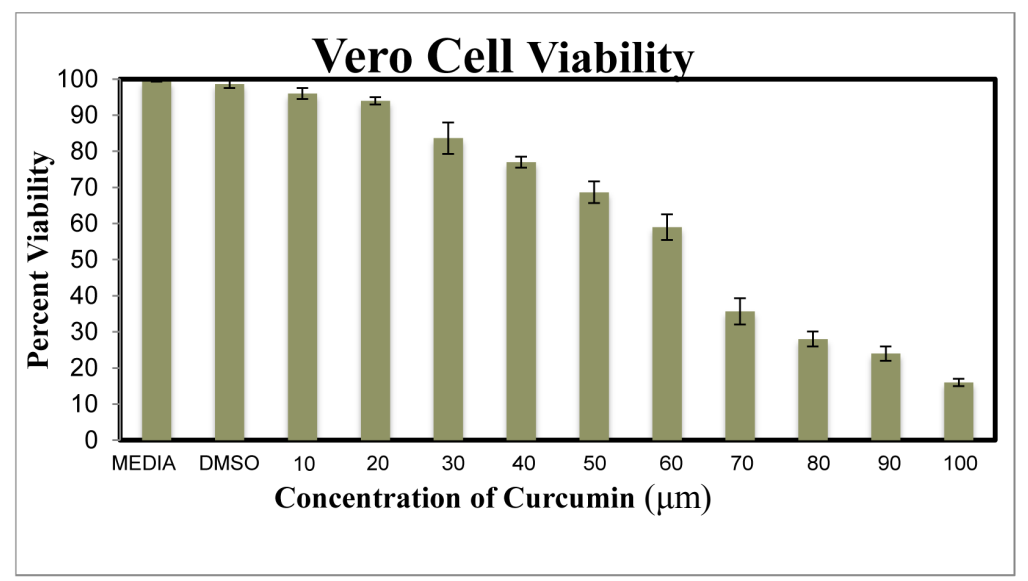

Figure 1. Cell viability studies of Cero cells treated with different concentrations of curcumin. Then number represents the mean percent viability of three replicates and y-error bars represent SD. 
$94 \%$, respectively, as compared to the control; 30 and $40 \mu \mathrm{M}$ percent viability is $84 \%$ and $77 \%$, respectively; at the concentrations of 50 and $60 \mu \mathrm{M}$, the percent viability decreased to $69 \%$ and $59 \%$, respectively. For concentrations of 70, 80, 90 and $100 \mu \mathrm{M}$, the percentages of viability are severely reduced to $36 \%, 28 \%, 24 \%$ and $16 \%$, respectively. The results suggested that concentrations from 10 to $30 \mu \mathrm{M}$ are not toxic to Vero cells. Therefore, concentrations up to $30 \mu \mathrm{M}$ can be used to treat HSV-1 and HSV-2 and study their inhibitory effects on viral infection.

\subsection{Cell Proliferation Assay with WST-1}

In this study, cell proliferation was examined after treating Vero cells with different concentrations $(30,40$ and $50 \mu \mathrm{M}$ ) of curcumin for 1 hour and then incubated for 24 hours. The WST-1 assay was carried out to monitor cellular metabolism. Each experiment was assayed in triplicate; the mean and SD were generated. The results of percent growth are shown in Figure 2. The proliferation assay results indicate that $30 \mu \mathrm{M}$ of curcumin is not inhibiting cell proliferation and the percent of growth is $93 \%$ relative to the control. This concentration is not toxic to the proliferation of Vero cells. However, concentrations of 40 and $50 \mu \mathrm{M}$ decrease the growth to $72 \%$ and $58 \%$ of the control. The results correlate well with cell viability study. The results suggested that the maximum concentration that could be used in this study is $30 \mu \mathrm{M}$ with no effect on cell viability and proliferation.

\subsection{WST-1 Antiviral Assay}

HSV-1 and HSV-2 were treated with different concentrations $(0,10,20,30,40$ and $50 \mu \mathrm{M})$ of curcumin for 1 hour and then used to infect Vero cells. The cell proliferation was analyzed using the WST-1 assay to determine the effect of curcurmin on cytopathic effect of HSV on Vero cells. The results are shown in Figure 3. For both HSV-1 and HSV-2, concentrations of 10 and $20 \mu \mathrm{M}$ curcumin have no effect on viral infection. The results are very similar to the untreated virus (data not shown). For curcumin treated HSV-1 at 30, 40 and $50 \mu \mathrm{M}$, the percentages of inhibition are $85 \%, 73 \%$ and $53 \%$, respectively. For HSV-2, the percent inhibition for 30,40 and 50 $\mu \mathrm{M}$ are $68 \%, 40 \%$ and $29 \%$, respectively. These results suggested that the minimum inhibitory concentration of curcumin on both HSV-1 and HSV-2 is $30 \mu \mathrm{M}$. The concentrations at 40 and $50 \mu \mathrm{M}$ of curcumin reduced the inhibitory effect due to the toxic effect of these concentrations on Vero cells as indicated in Figure 1 and Figure 2. The data suggested that curcumin at $30 \mu \mathrm{M}$ can inhibit both HSV-1 and HSV-2, with more efficient inhibition of HSV-1 in cultured Vero cells.

\subsection{Viral Titer Determination using Plaque Assay}

Plaque assay was carried out to quantitatively study the effect of $30 \mu \mathrm{M}$ of curcumin on the viral plaque production. Results are shown in Table 1, Figure 4 and Figure 5. The PFU $/ \mathrm{mL}$ of HSV-1 infected Vero cells is $2.35 \times$ $10^{8}$, and PFU/mL of curcumin treated HSV-1 is reduced to $1.8 \times 10^{7}$ and $92 \%$ inhibition. The PFU $/ \mathrm{mL}$ of HSV-2 infected Vero cell is $1.8 \times 10^{8}$, and PFU/mL of curcumin treated HSV-2 is $2.1 \times 10^{7}$. Curcumin inhibits

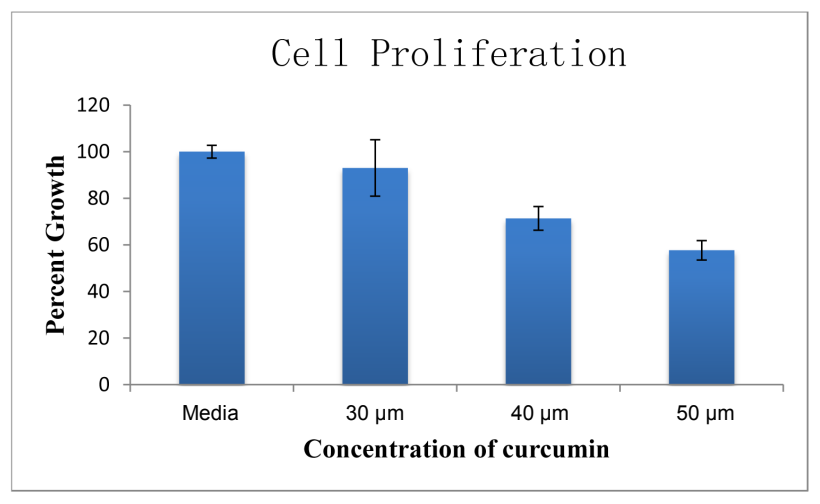

Figure 2. Cell proliferation assay of Vero cells treated with different concentrations of curcumin. The number represents the mean percent growth relative to the untreated control of three replicates and y-error bars. 


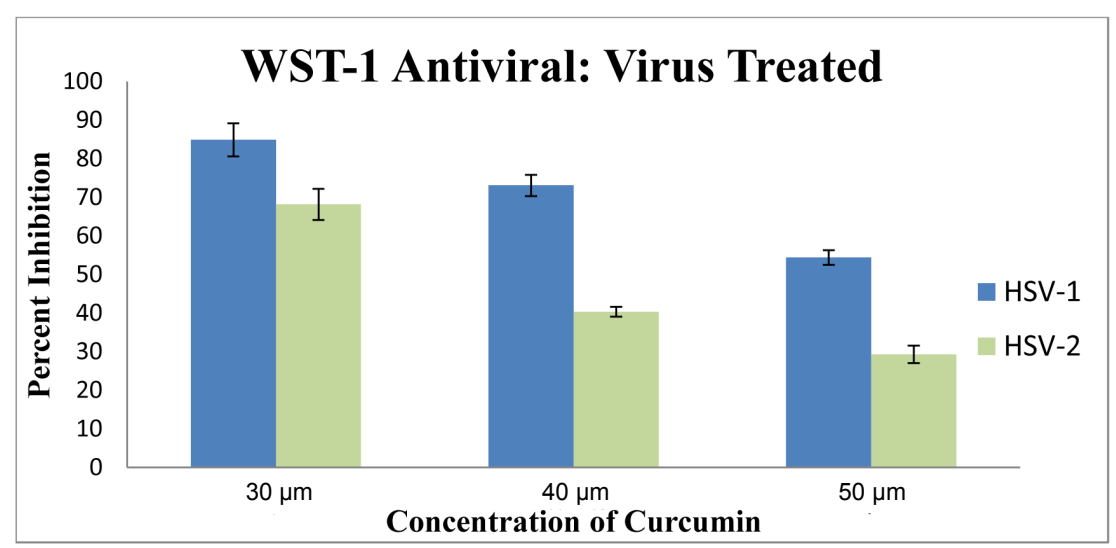

Figure 3. WST-1 assay for HSV-1 and HSV-2 treated with different concentrations of curcumin. The numbers represent the mean percent of three replicates and y-error bars represent SD.

Table 1. PFU/mL and percentage inhibition of curcumin $(30 \mu \mathrm{M})$ treated and untreated HSV-1 and HSV-2.

\begin{tabular}{cccc} 
& & & \\
& Viral Titer $(\mathrm{PFU} / \mathrm{mL})$ & Curcumin Treated Virus & Percentage Inhibition $(\%)$ \\
\hline HSV-1 & $2.35 \times 10^{8}$ & $1.8 \times 10^{7}$ & 92.34 \\
HSV-2 & $1.8 \times 10^{8}$ & $2.1 \times 10^{7}$ & 88.33 \\
\hline
\end{tabular}

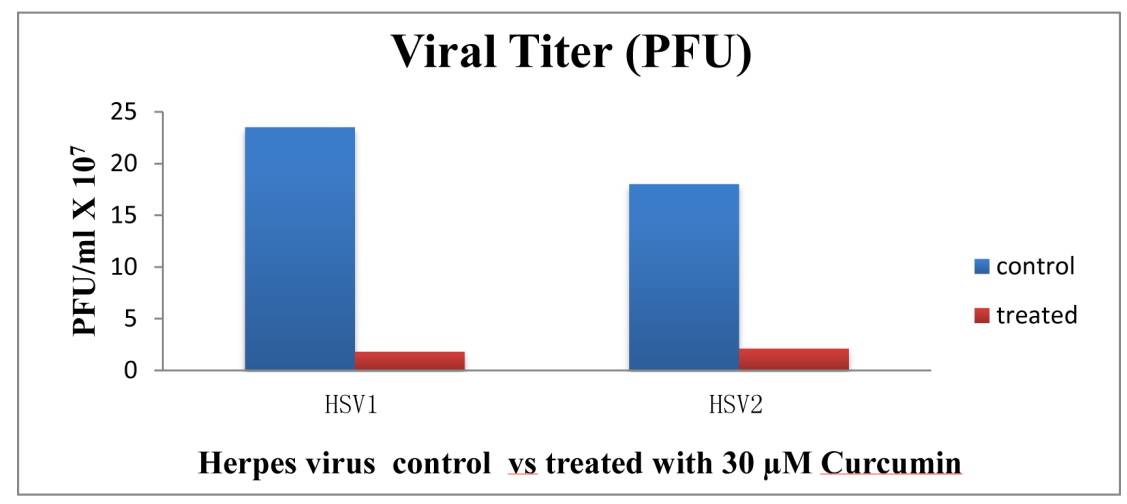

Figure 4. Plaque assay of HSV-1 and HSV-2 treated with curcumin and untreated

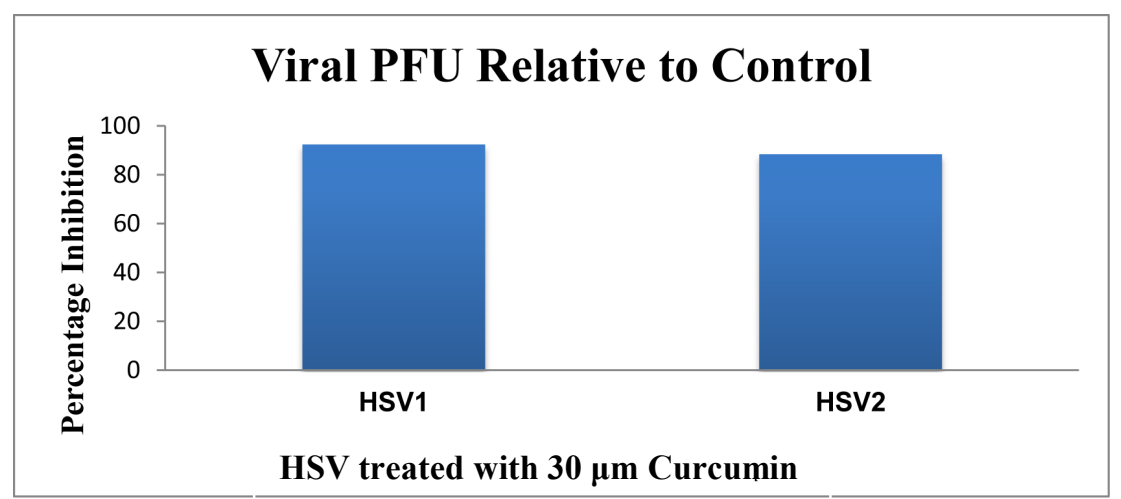

Figure 5. Percentage of inhibition of curcumin-treated HSV-1 and HSV-2 relative to the control. 
$88 \%$ PFUs/mL in HSV-2. This suggests that curcumin is able to inhibit both HSV-1 and HSV-2 and is more potent in inhibiting HSV-1 than HSV-2. This result correlates well with the WST-1 antiviral assay.

\subsection{Fluorescence Microscopy Observation of HSV-Infected Vero Cells and Curcumin-Treated HSV Infected Vero Cells}

Fluorescence microscopy observations were employed to determine if curcumin blocks a stage of the HSV replication cycle. Both HSV-1 and HSV-2 viruses used in this study contain the sequence for green fluorescent protein (see materials and methods), thus the localization of GFP was observed to evaluate the processes of the viral replication cycle. DAPI stain was also used to study the integrity of the nucleus in Vero cells and infected Vero cells. Vero cells were used as the negative control and HSV infected Vero cells were used as the positive control. Curcumin with the concentration of $30 \mu \mathrm{M}$ was used to treat HSV-1 and HSV-2 for one hour prior to viral infection and the Images were taken at 12 hours post infection. The results of green fluorescence, DAPI stain and overlay images are shown in Figures 6-8. Vero cells without any treatment or infection are shown in Figure 6. From the green fluorescence image (Figure 6(A)), some areas have light smooth green background but no sharp green fluorescent particles are observed. DAPI stained nuclei show clear margins and no granules are observed, thus illustrating the integrity of the nucleus in normal cells (Figure 6(B)). The overlay image shows green fluorescence (for detection of viral particles) and blue fluorescence (for integrity of cell nuclei), and their relative intensity (Figure $6(C)$ ). These images are used as a reference to compare each of the treated and non-treated viral infected samples.

Figure 7 shows the HSV-1 infected Vero cells and curcumin treated HSV-1 infected Vero cells at 12 hours post infection. In HSV-1 infected Vero cells (Figures $7(\mathbf{A})-(\mathbf{C})$ ), the cell morphology changed and appeared more rounded than the normal flat Vero cells (Figure 6). The appearance of green fluorescence is the tegument tagged HSV-1 GFP capsid that represents one of the final stages of the viral reproductive cycle. Figure 7(A) clearly indicated that there are significant amounts of GFP expression in HSV-1 infected Vero cells. DAPI stain (Figure 7(B)) of HSV-1 infected cells indicates nuclear changes with granulation and demargination. The overlay image (Figure $7(\mathrm{C})$ ) demonstrates the sharp green particles on blue nuclei. In the curcumin treated HSV-1 infected cells (Figures $7\left(\mathbf{A}^{\prime}\right)-\left(\mathbf{C}^{\prime}\right)$ ), the images are very similar to the uninfected cell alone images. These results suggest that the curcumin treatment affects the viral replication cycle and prevents viral production in the treated samples.

HSV-2 used in this study, is tagged with GFP on the VP26 capsid protein. The expression of GFP also indicates one of the final stages of the viral replication cycle. The results of the study with HSV-2 are similar to the findings of the HSV-1 study (Figure 8). In HSV-2 infected cells, clear morphological changes in the cells, significant GFP expression with sharp green particles (Figure 8(A)), loss of nuclear integrity (Figure 8(B)) and obvious green fluorescence on the overlay image are observed (Figure 8(C)). The curcumin treated HSV-2 infected cells (Figures $8\left(\mathbf{A}^{9}\right)-\left(\mathbf{C}^{9}\right)$ ) are very different from the untreated HSV-2 infected samples and very similar to the untreated cells alone. The results from this fluorescence microscopy study suggest that curcumin is able to inhibit both HSV-1 and HSV-2 replication and prevent completion of the viral lytic cycle.

\subsection{Viral Adsorption and Penetration Assay}

In order to determine one of the mechanisms of inhibition of HSV-1 and HSV-2 by curcumin, studies on adsorption and penetration, the initial steps of viral lytic cycle, were carried out. The results are shown in Table 2.

(a)

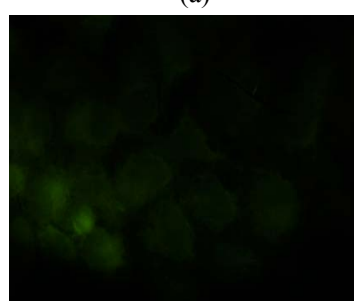

(b)

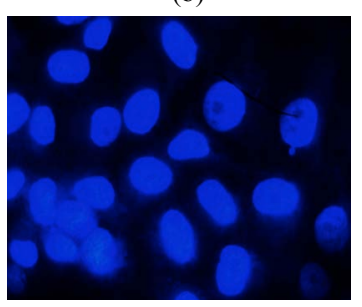

(c)

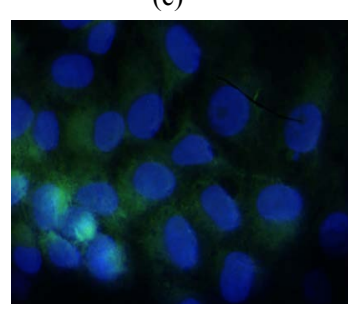

Figure 6. Fluorescence images of Vero cells. (a) Green fluorescence GFP expression; (b) DAPI stain; (c) Overlay of GFP and DAPI stain. 

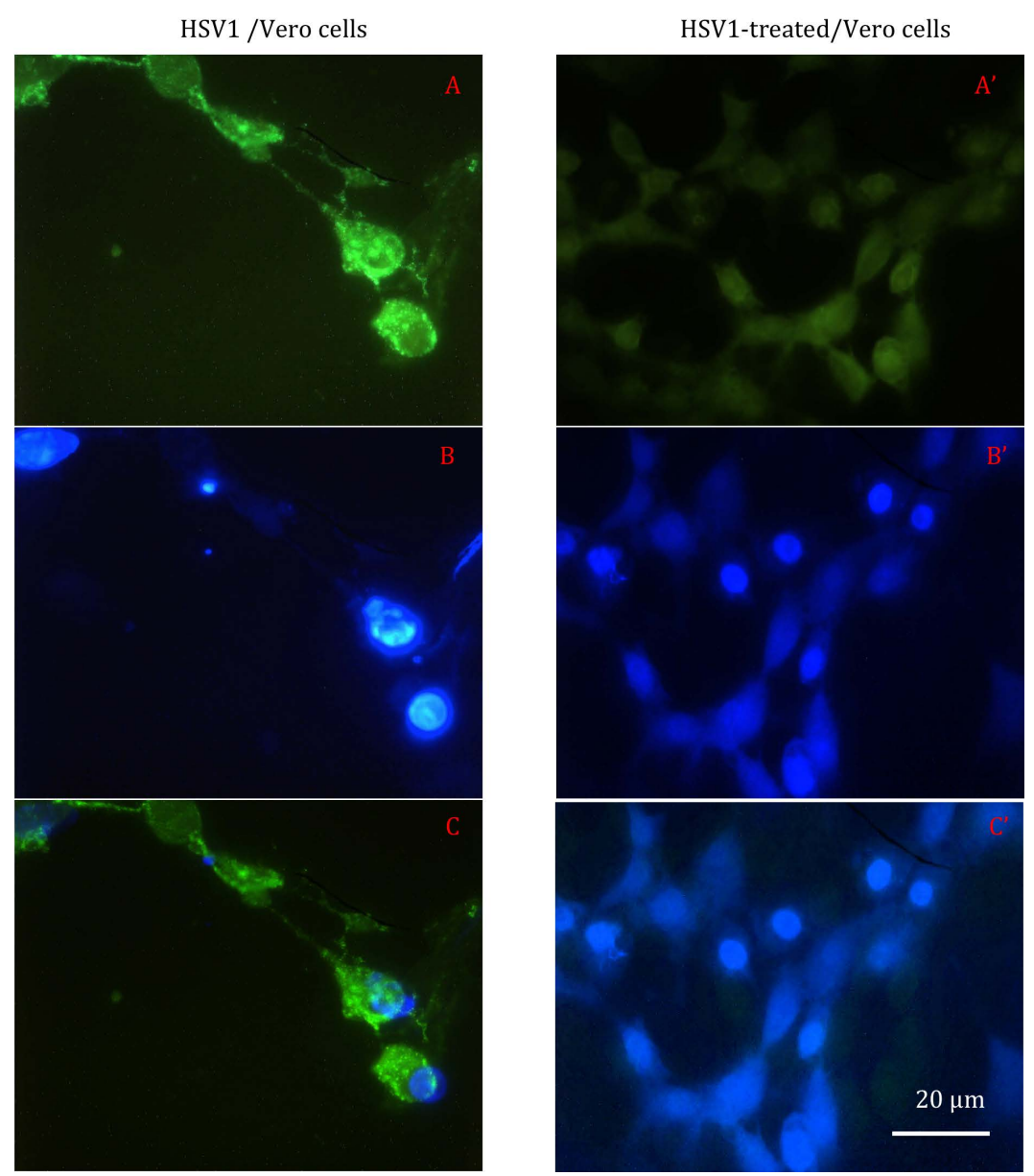

Figure 7. Fluorescence images of curcumin-treated and untreated HSV-1 infected Vero cells. A. GFP expression in HSV-1 infected Vero cells; A'. GFP expression in treated HSV-1 infected Vero cells; B. DAPI of untreated HSV-2 infected cells; B'. DAPI stain of treatedHSV-1 infected cells; C. Overlay of GFP and DAPI stain of untreated HSV-1 infected cells; C'. Overlay of GFP and DAPI stain of treated HSV-1 infected cells.

For the adsorption assay, PFU/mL for untreated HSV-1 is $2.4 \times 10^{6}$ and for treated is $3.5 \times 10^{5}$, respectively. The percent of inhibition is $85.4 \%$ compared to the untreated control. PFU $/ \mathrm{mL}$ for untreated HSV -2 is $8 \times 10^{6}$ and for treated is $2 \times 10^{5}$ respectively. The percent of inhibition is $97.5 \%$. For the penetration assay, both HSV-1 and HSV-2 with treated and untreated samples, the PFUs $/ \mathrm{mL}$ are very similar. The results indicate that curcumin is able to inhibit viral adsorption but is not able to inhibit viral penetration. Thus, the studies suggest that curcumin blocks adsorption, an initial stage of viral infection.

\section{Discussions}

There is considerable evidence that curcumin demonstrates antiviral activity against a wide variety of viruses, including Herpes simplex viruses by a variety of modes of action [29]-[38]. However, there still remains a need to further investigate the application of curcumin as an antiviral agent against Herpes simplex viruses and its mode of action because Herpes simplex virus infections continue to be a significant health problem in the United States and worldwide. Recurrent HSV infections result in cold sores and painful lesions. Current treatments to reduce transmission, such as acyclovir, are available but may be expensive and may have undesirable side effects and drawbacks [39] [40]. There remains a need for safe, lower cost alternative treatments for HSV infections. Curcumin, at $30 \mu \mathrm{M}(11.05 \mu \mathrm{g} / \mathrm{mL})$, has the potential to act as a therapeutic agent to reduce the transmission of Herpes simplex viruses. 
HSV2 /Vero cells

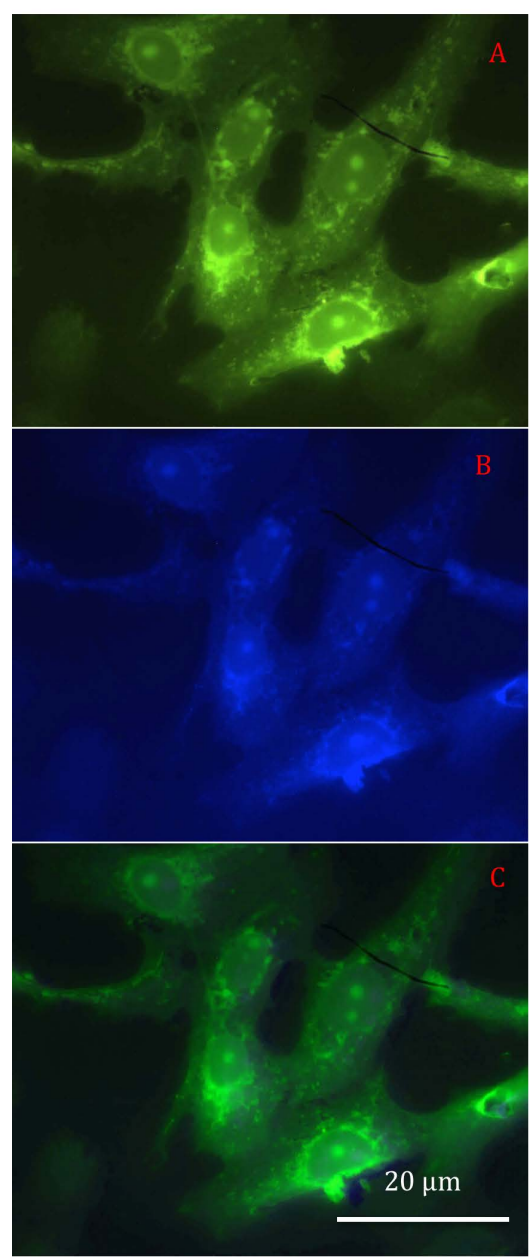

Figure 8. Fluorescence images of curcumin-treated and untreated HSV-2 infected Vero cells. A. GFP expression in HSV-2 infected Vero cells; A'. GFP expression in treated HSV-2 infected Vero cells; B. DAPI of untreated HSV-2 infected cells; B'. DAPI stain of treatedHSV-2 infected cells; C. Overlay of GFP and DAPI stain of untreated HSV-2 infected cells; C'. Overlay of GFP and DAPI stain of treated HSV-2 infected cells.

Table 2. PFU and percent inhibition of adsorption and penetration assays of curcumin-treated and untreated HSV-1 and HSV-2.

\begin{tabular}{cccc}
\hline & $\begin{array}{c}\text { Adsorption Assay } \\
(\mathrm{PFU} / \mathrm{mL})\end{array}$ & $\begin{array}{c}\text { \% of Inhibition relative } \\
\text { to untreated }\end{array}$ & $\begin{array}{c}\text { Penetration Assay } \\
(\text { PFU/ml })\end{array}$ \\
Untreated Titer & $2.4 \times 10^{8}$ & HSV-1 & $1.2 \times 10^{8}$ \\
Treated Titer & $3.5 \times 10^{5}$ & 85.4 & $1.8 \times 10^{8}$ \\
& & HSV-2 & $7 \times 10^{5}$ \\
Untreated Titer & $8 \times 10^{8}$ & & $7 \times 10^{5}$ \\
Treated Titer & $2 \times 10^{5}$ & 97.5 & 0 \\
\hline
\end{tabular}

Our results indicate that the minimum inhibitory concentration of curcumin $(30 \mu \mathrm{M})$ is safe and non-cytotoxic to cultured cells, consistent with previous studies [23] [31] [33] [41]. Curcumin, at concentrations tested, had no negative effects on either cell viability or cell proliferation. The antiviral and antitumor effectiveness and safety 
of curcumin were also tested in vivo [42] [43]. Previous studies have investigated the effects of treating cells with curcumin on HSV-1 infection [35] or treating HSV-2 virions with curcumin [36]. This study is unique in investigating the effect on the infection cycle of curcumin-treated HSV-1 and HSV-2 virions.

The inhibitory effects of curcumin were measured by a variety of assays including WST-1 antiviral assay, plaque assays, and by fluorescent microscopy. Treatment of virions with non-cytotoxic concentrations of curcumin for 1 hour inhibited the infection cycles of both HSV-1 and HSV-2. Viral titers were reduced for both HSV-1 and HSV-2, but more efficiently for HSV-1. Treatment did not, however, inactivate all virions. These results were confirmed by fluorescent microscopy.

Previous studies have demonstrated that curcumin inhibits entry of hepatitis $C$ viruses [32], influenza and paramyxovirus NDV [33] [41]. Therefore, this study investigated possible mechanisms of inhibition by focusing on events in early stages of the viral life cycles.

This study demonstrated that treatment of HSV-1 and HSV-2 virus particles with curcumin affects an early stage of Vero cell infections. The processes of adsorption and penetration were investigated but virus titers were reduced during adsorption, with no significant effect on penetration.

\section{Acknowledgements}

We thank Dr. Andrea Bertke of Virginia Tech University for generously donating HSV-2 VP26-GFP. This research was supported in part by the Science Honors Innovation Program at Montclair State University, the Benjamin Cummings/MACUB Student Research Grant, and the Montclair State University Faculty Scholarship Program.

\section{Conflict of Interest}

The authors declare that there is no conflict of interest.

\section{References}

[1] Nahmias, A.J., Lee, F.K. and Beckman-Nahmias, S. (1990) Sero-Epidemiological and -Sociological Patterns of Herpes Simplex Virus Infection in the World. Scandinavian Journal of Infectious Diseases Supplementum, 69, 19-36.

[2] Lafferty, W.E., Coombs, R.W., Benedetti, J., Critchlow, C. and Corey, L. (1987) Recurrences after Oral and Genital Herpes Simplex Virus Infection. Influence of Site of Infection and Viral Type. New England Journal of Medicine, 316, 1444-1449. http://dx.doi.org/10.1056/nejm198706043162304

[3] Akhtar, J. and Shukla, D. (2009) Viral Entry Mechanisms: Cellular and Viral Mediators of Herpes Simplex Virus Entry. Federation of European Biochemical Societies Journal, 276, 7228-7236. http://dx.doi.org/10.1111/j.1742-4658.2009.07402.x

[4] Garner, J.A. (2003) Herpes Simplex Virion Entry into and Intracellular Transport within Mammalian Cells. Advanced Drug Delivery Reviews, 55, 1497-1513. http://dx.doi.org/10.1016/j.addr.2003.07.006

[5] O’Donnell, C.D., Kovacs, M., Akhtar, J., Valyi-Nagy, T. and Shukla, D. (2010) Expanding the Role of 3-O Sulfated Heparan Sulfate in Herpes Simplex Virus Type-1 Entry. Virology, 397, 389-398. http://dx.doi.org/10.1016/j.virol.2009.11.011

[6] Whitley, R.J., Kimberlin, D.W. and Roizman, B. (1998) Herpes Simplex Viruses. Clinical Infectious Diseases, 26, 541-555. http://dx.doi.org/10.1086/514600

[7] Hafezi, W., Lorentzen, E.U., Eing, B.R., Müller, M., King, N.J.C., Klupp, B., Metenleiter, T.C. and Kühn, J.E. (2012) Entry of Herpes Simplex Virus Type 1 (HSV-1) into the Distal Axons of Trigeminal Neurons Favors the Onset of Nonproductive, Silent Infection. PLoS Pathogens, 8, e1002679. http://dx.doi.org/10.1371/journal.ppat.1002679

[8] Lafferty, W.E., Downey, L., Celum, C. and Wald, A. (2000) Herpes Simplex Virus Type 1 as a Cause of Genital Herpes: Impact on Surveillance and Prevention. The Journal of Infectious Diseases, 181, 1454-1457. http://dx.doi.org/10.1086/315395

[9] Biškup, U.G., Uršič, T. and Petrovec, M. (2015) Laboratory Diagnosis and Epidemiology of Herpes Simplex 1 and 2 Genital Infections. Acta Dermatovenerologica, 24, 31-35.

[10] Schiffer, J.T. and Corey, L. (2009) New Concepts in Understanding Genital Herpes. Current Infectious Disease Reports, 11, 457-464. http://dx.doi.org/10.1007/s11908-009-0066-7

[11] Xu, F., Schillinger, J.A., Sternberg, M.R., Johnson, R.E., Lee, F.K., Nahmias, A.J. and Markowitz, L.E. (2002) Seroprevalence and Coinfection with Herpes Simplex Virus Type 1 and Type 2 in the United States, 1988-1994. The Jour- 
nal of Infectious Diseases, 185, 1019-1024. http://dx.doi.org/10.1086/340041

[12] Xu, F., Sternberg, M.R., Kottiri, B.J., McQuillan, G.M., Lee, F.K., Nahmias, A.J., Berman, S.M. and Markowitz, L.E. (2006) Trends in Herpes Simplex Virus Type 1 and Type 2 Seroprevalence in the United States. JAMA, 296, 964-973. http://dx.doi.org/10.1001/jama.296.8.964

[13] Looker, K.J., Garnett, G.P. and Schmid, G.P. (2008) An Estimate of the Global Prevalence and Incidence of Herpes Simplex Virus Type 2 Infection. Bulletin of the World Health Organization, 86, 805-812. http://dx.doi.org/10.2471/BLT.07.046128

[14] Weiss, H., Buvé, A., Robinson, N., Van Dyck, E., Kahindo, M., Anagonou, S., Musonda, R., Zekeng, L., Morison, L., Caraël, M., Laga, M. and Hayes, R.J. (2001) The Epidemiology of HSV-2 Infection and Its Association with HIV Infection in Four Urban African Populations. AIDS, 15, S97-S108. http://dx.doi.org/10.1097/00002030-200108004-00011

[15] Fujie, X., Lee, F.K., Morrow, R.A., Sternberg, M.R., Luther, K.E., Dubin, G. and Markowitz, L.E. (2007) Seroprevalence of Herpes Simplex Virus Type 1 in Children in the United States. Journal of Pediatrics, 151, 374-377. http://dx.doi.org/10.1016/j.jpeds.2007.04.065

[16] Uribe-Salas, F., Palma-Coca, O., Sánchez-Alemán, M.A., Olamendi, M., Juárez-Figueroa, L. and Conde-Glez, C.J. (2009) Population-Based Prevalence of Antibodies against Herpes Simplex Virus Type 2 and Socio-Demographic Characteristic of Mexico. Transactions of the Royal Society of Tropical Medicine and Hygiene, 103, 151-158. http://dx.doi.org/10.1016/j.trstmh.2008.10.033

[17] Waweru, C.W. (2008) PIN 46 Country Assessment to Determine Factors Influencing the Cost, Availability and Distribution of Acyclovir in Eight Sub-Saharan African Countries. Value in Health, 11, A106-A107. http://dx.doi.org/10.1016/S1098-3015(10)70344-2

[18] Cantatore, A.C., Randall, S.D., Traum, D. and Adams, S.D. (2013) Effect of Black Tea Extract on Herpes Simplex Virus-1 Infection of Cultured Cells. BMC Complementary and Alternative Medicine, 13, 139. http://dx.doi.org/10.1186/1472-6882-13-139

[19] de Oliveira, A., Adams, S.D., Lee, L.H., Murray, S.R., Hsu, S.D., Hammond, J.R., Dickinson, D., Chen, P. and Chu, T.-C. (2013) Inhibition of Herpes Simplex Virus Type 1 with the Modified Green Tea Polyphenol Palmitoyl-Epigallocatechin Gallate. Food and Chemical Toxicology, 52, 207-215. http://dx.doi.org/10.1016/j.fct.2012.11.006

[20] Fortin, H., Vigor, C., Lohezic-Dévéhat, F., Robin, V., Le Bossé, B., Boustie, J.M. and Amoros, M. (2002) In Vitro Antiviral Activity of Thirty-Six Plants from La Réunion Island. Fitoterapia, 73, 346-350. http://dx.doi.org/10.1016/S0367-326X(02)00080-1

[21] Andrighetti-Fröhner, C.R., Sincero, T.C., da Silva, A.C., Savi, L.A., Gaido, C.M., Bettega, J.M., Mancini, M., de Almeida, M.T., Barbosa, R.A., Farias, M.R., Barardi, C.R. and Simöes, C.M. (2005) Antiviral Evaluation of Plants from Brazilian Atlantic Tropical Forest. Fitoterapia, 76, 374-378. http://dx.doi.org/10.1016/j.fitote.2005.03.010

[22] Yarmolinsky, L., Hulelhel, M., Zaccai, M. and Ben-Shabat, S. (2012) Potent Antiviral Flavone Glycosides from Ficus benjamina Leaves. Fitoterapia, 83, 362-367. http://dx.doi.org/10.1016/j.fitote.2011.11.014

[23] Fioravanti, R., Celestino, I., Costi, R., Crucitti, G.C., Pescatori, L., Mattiello, L., Novellino, E., Checconi, P., Palamara, A.T., Nencioni, L. and Di Santo, R. (2012) Effects of Polyphenol Compounds on Influenza A Virus Replication and Definition of Their Mechanism of Action. Biorganic \& Medicinal Chemistry, 20, 5046-5052. http://dx.doi.org/10.1016/j.bmc.2012.05.062

[24] Chiang, L.C., Chaing, W., Liu, M.C. and Lin, C.C. (2003) In Vitro Antiviral Activities of Caesalpinia pulcherrima and Its Related Flavonoids. Journal of Antimicrobial Chemotherapy, 52, 194-198. http://dx.doi.org/10.1093/jac/dkg291

[25] Hosseinzadeh, L., Behraven, J., Mosaffa, F., Bahrami, G., Bahrami, A. and Karimi, G. (2011) Curcumin Potentiates Doxorubicin-Induced Apoptosis in H9c2 Cardiac Muscle Cells through Generation of Reactive Oxygen Species. Food and Chemical Toxicology, 49, 1102-1109. http://dx.doi.org/10.1016/j.fct.2011.01.021

[26] Liang, G., Yang, S., Zhou, H. and Shao, L. (2009) Synthesis, Crystal Structure and Anti-Inflammatory Properties of Curcumin Analogues. European Journal of Medicinal Chemistry, 44, 915-919. http://dx.doi.org/10.1016/j.ejmech.2008.01.031

[27] Debata, R., Castellanos, M.R., Fata, J.E., Baggett, S., Rajupet, S., Szerszen, A., Begum, S., Mata, A., Murty, V.V., Opitz, L.M. and Banerjee, P. (2013) A Novel Curcumin-Based Vaginal Cream Vacurin Selectively Eliminates Apposed Human Cervical Cancer Cells. Gynecologic Oncology, 129, 145-153. http://dx.doi.org/10.1016/j.ygyno.2012.12.005

[28] Duvoix, A., Blasius, R., Delhalle, S., Schnekenburger, M., Morceau, F., Henry, E., Dicato, M. and Diederich, M. (2005) Chemopreventive and Therapeutic Effects of Curcumin. Cancer Letters, 223, 181-190. http://dx.doi.org/10.1016/j.canlet.2004.09.041

[29] Rechtman, M.M., Bar-Yishay, I., Fishman, S., Adamovich, Y., Shaul, Y., Halpern, Z. and Shlomai, A. (2010) Curcu- 
min Inhibits Hepatitis B Virus Down Regulation of the Metabolic Coactivator PGC-1 a. FEBS Letters, 584, 2485-2490. http://dx.doi.org/10.1016/j.febslet.2010.04.067

[30] Kim, H.J., Yoo, H.S., Kim, J.C., Park, C.S., Choi, M.S., Kim, M., Choi, H., Min, J.S., Kim, Y.S., Yoon, S.W. and Ahn, J.K. (2009) Antiviral Effect of Curcuma longa Linn Extract against Hepatitis B Virus Replication. Journal of Ethnopharmacology, 124, 189-196. http://dx.doi.org/10.1016/j.jep.2009.04.046

[31] Kim, K., Kim, K.H., Kim, H.Y., Cho, H.K., Sakamoto, N. and Cheong, J. (2010) Curcumin Inhibits Hepatitis C Virus Replication via Suppressing Aktk-SREBP-1 Pathway. FEBS Letters, 584, 707-712. http://dx.doi.org/10.1016/j.febslet.2009.12.019

[32] Anggakusuma, Colpitts, C.C., Schang, L.M., Rachmawati, H., Frentzen, A., Pfaender, S., Behrendt, P., Brown, R.J., Bankwitz, D., Steinmann, J., Ott, M., Meuleman, P. and Rice, C.M. (2013) Turmeric Curcumin Inhibits Entry of All Hepatitis C Virus Genotypes into Human Liver Cells. Gut, 63, 1137-1149.

[33] Chen, D.-Y., Shien, J.-H., Tiley, L., Chiou, S.-S., Wang, S.-Y., Chang, T.-J., Lee, Y.-J., Chan, K.-W. and Hsu, W.-L. (2010) Curcumin Inhibits Influenza Virus Infection and Haemagglutination Activity. Food Chemistry, 119, 1346-1351. http://dx.doi.org/10.1016/j.foodchem.2009.09.011

[34] Qin, Y., Lin, X., Chen, Y., Wu, S., Si, X., Wu, H., Zhai, X., Wang, Y., Tong, L., Pan, B., Zhong, X., Wang, T., Zhao, W. and Zhang, Z. (2014) Curcumin Inhibits the Replication of Enterovirus 71 in Vitro. Acta Pharmaceutica Sinica B, 4, 284-294. http://dx.doi.org/10.1016/j.apsb.2014.06.006

[35] Marbawati, D. and Umniyati, S.R. (2015) Effects of Curcumin and Pentagamavunon-0 against Dengue-2 Virus Infection in Vero Cells; an in Vitro Study. Procedia Environmental Sciences, 23, 215-221. http://dx.doi.org/10.1016/j.proenv.2015.01.033

[36] Bourne, K.Z., Bourne, N., Reising, S.F. and Stanberry, L.R. (1999) Plant Products as Topical Microbicide Candidates: Assessment of in Vitro and in Vivo Activity against Herpes Simplex Virus Type 2. Antiviral Research, 42, 219-226. http://dx.doi.org/10.1016/S0166-3542(99)00020-0

[37] Kutluay, S.B., Doroghazi, J., Roemwe, M.E. and Triezenberg, S.J. (2008)Curcumin Inhibits Herpes Simplex Virus Immediate-Early Gene Expression by a Mechanism Independent of p300/CBP Histone Acetyltransferase Activity. Virology, 373, 239-247. http://dx.doi.org/10.1016/j.virol.2007.11.028

[38] Chiang, L.C., Chiang, W., Liu, M.C. and Lin, C.C. (2003) In Vitro Antiviral Activities of Caesalpinia pulcherrima and Its Related Flavonoids. Journal of Antimicrobial Chemotherapy, 52, 194-198. http://dx.doi.org/10.1093/jac/dkg291

[39] Brady, R. and Bernstein, D. (2004) Treatment of Herpes Simplex Infections. Antiviral Research, 61, 73-81. http://dx.doi.org/10.1016/j.antiviral.2003.09.006

[40] Fatahzadeh, M. and Schwartz, R.A. (2007) Human Herpes Simplex Virus Infections: Epidemiology, Pathogenesis, Symptomatology, Diagnosis, and Management. Journal of the American Academy of Dermatology, 57, 737-763. http://dx.doi.org/10.1016/j.jaad.2007.06.027

[41] Chen, T.Z., Chen, D.-Y., Wen, H.-W., Chiou, S.-S., Chen, J.-M., Wong, M.-L. and Hsu, W.-L. (2013) Inhibition of Enveloped Viruses Infectivity by Curcumin. PLOS ONE, 8, e62482. http://dx.doi.org/10.1371/journal.pone.0062482

[42] Lu, Y., Lei, N., Wang, D., An, Z., Li, G., Han, F., Liu, H. and Liu, L. (2014) Protective Effect of Curcumin against Cytomegalovirus Infection in Balb/c Mice. Environmental Toxicology and Pharmacology, 37, 1140-1147. http://dx.doi.org/10.1016/j.etap.2014.04.017

[43] Debata, P.R., Castellanos, M.R., Fata, J.E., Baggett, S., Rajupet, S., Szerszen, A., Begum, S., Mata, A., Murty, V.V., Opitz, L.M. and Banerjee, P. (2012) A Novel Curcumin-Based Vaginal Cream Vacurin Selectively Eliminates Apposed Human Cervical Cancer Cells. Gynecologic Oncology, 129, 145-153. http://dx.doi.org/10.1016/j.ygyno.2012.12.005 